\title{
EXPERIMENTAL INVESTIGATION ON THE EFFECT OF ADDING CYCLOHEXANONE TO GASOLINE IN SI ENGINE EMISSIONS AND PERFORMANCE
}

\author{
Abed Al-Khadhim M. Hassan \\ Abdulkadhim.m.hadi@uotechnology.edu.iq
}

Sadeq Abdul-Azeez Jassam

me.19.04@grad.uotechnology.edu.iq

Mechanical Engineering Department, University of Technology, Baghdad-Iraq

\begin{abstract}
The aim of the present work is to investigate the influence of adding some ketone compounds on the performance, emissions, heat balance and exhaust gas temperature of spark ignition engine. The ketone used in this study is cyclohexanone $\left(\mathrm{C}_{6} \mathrm{H}_{10} \mathrm{O}\right)$. This ketone has been added to the base fuel (gasoline) with three concentration ranges $(3,6$ and $9 \%$ ) respectively. All experimental tests were carried out on gasoline engine type (Nissan QG18DE), four cylinders, 4-stroke, direct injection, with compression ratio (9.5:1). The acquired results showed that adding of ketones affect the physical properties of gasoline. Where the density changed from $\left(710 \mathrm{~kg} / \mathrm{m}^{3}\right)$ for net gasoline to $\left(740.8 \mathrm{~kg} / \mathrm{m}^{3}\right)$ for cyclohexanone at adding ratio of $(9 \%)$. The octane number also increased from (86) for pure gasoline to (97.7) for fuel with $9 \%$ cyclohexanone. The calorific value will be decrease from $(43000 \mathrm{~kJ} / \mathrm{kg})$ for gasoline to (42077.5) for cyclohexanone at adding ratio of (9\%). The addition of ketones improves the emissions characteristic of engine. The best reduction of (UHC, CO_2, CO and NOx) was $(49.04,22.43,35.02$ and $42.14 \%)$ recorded by cyclohexanone addition at ratio of (9\%). In the case of performance, all parameters of performance improved by adding ketones. The brake specific fuel consumption reduced by $(8.9 \%)$ by adding $(9 \%)$ of cyclohexanone which recorded as the best reduction through all types. The best increment of brake power, brake thermal efficiency, brake mean effective pressure and volumetric efficiency was $(17.3,8.98$, 17.25 and $12.7 \%$ ) is achieved by adding (9\%) of cyclohexanone. Also, the exhaust gas temperature will be increase by adding ketones. The percentage increasing of exhaust gas temperature was $(28.31 \%)$ recorded by cyclohexanone addition at ratio of $(9 \%)$. In the case of heat balance, the best increment of total heat internal energy was (6.59) at (9\%) of cyclohexanone.
\end{abstract}

Keywords: ketone, cyclohexanone, emissions, performance, gasoline

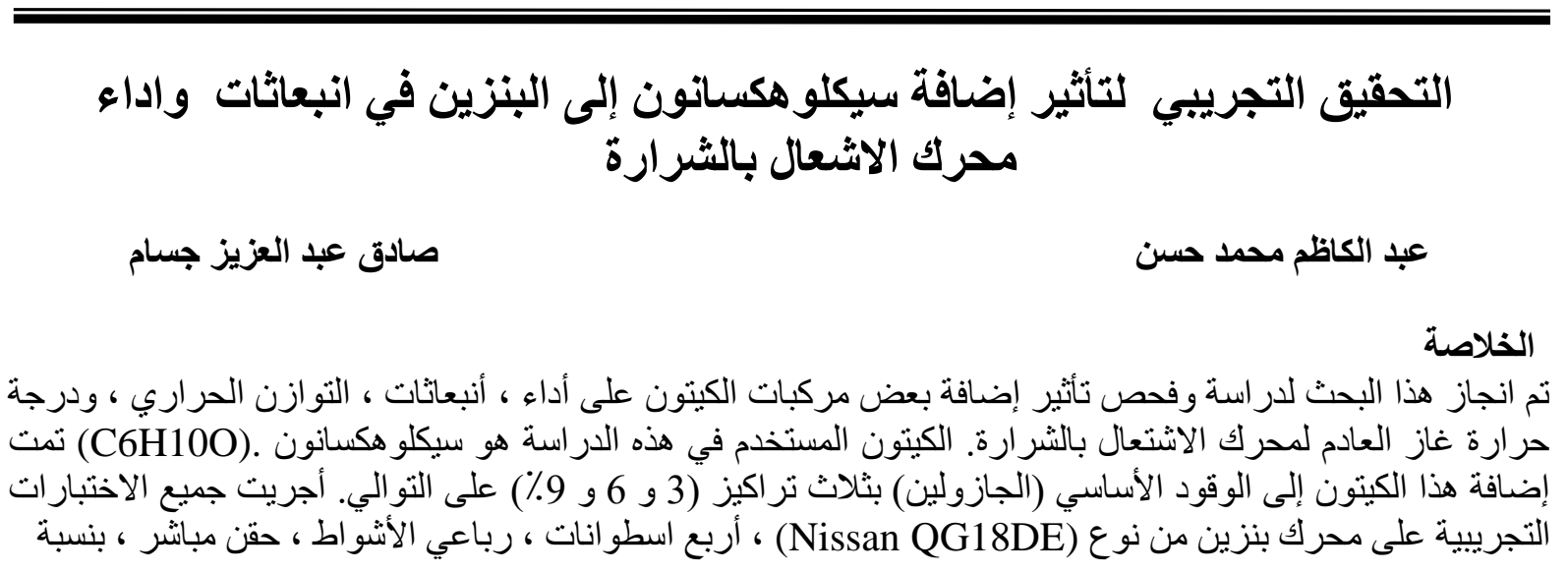




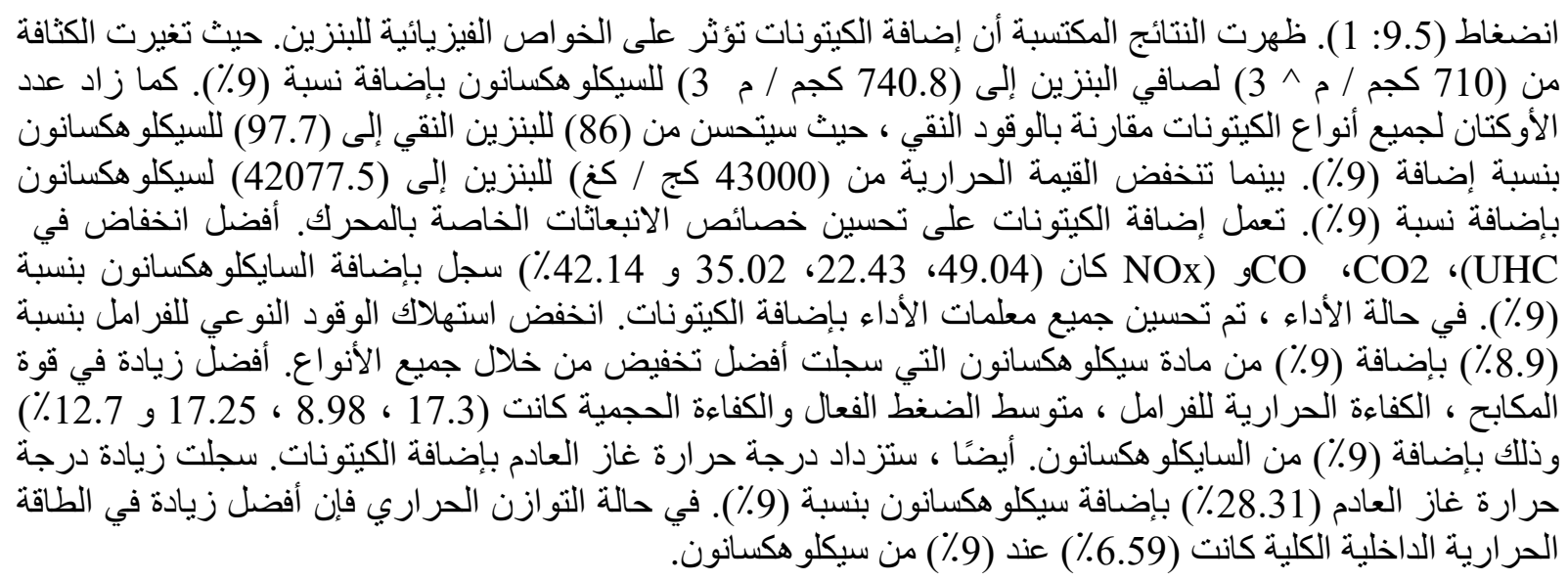

\section{INTRODUCTION}

The performance levels evaluation of any engine relies upon certain key parameters, among of them being focusing upon the Brake power (B.p) performance, Brake thermal efficiency ( $\left.\eta_{\mathrm{Bth}}\right)$, Brake specific fuel consumption (B.s.f.c), the ratio of air to fuel, and the speed of engine. Most importantly being the used fuel kind that's regarded to be the significant indicator which affects the performance of engine (Abdel-Rahman,A.A. 1998,2014). Also, the enormous increase in environmental pollution caused by combustion processes makes it essential that solutions required for their reduction. This problem is caused by the exhaust emission from the internal-combustion engines and other combustion system. The reactions that occur in the engine combustion process not only produce substances such as $\mathrm{CO}_{2}, \mathrm{H}_{2} \mathrm{O}$ and $\mathrm{N}_{2}$, but also various pollutants which are found in the engine exhaust. The three main pollutants which are subject to exhaust emission legislation are carbon monoxide (CO), unburned hydrocarbons (HC) and nitrogen oxides $\left(\mathrm{NO}_{\mathrm{x}}\right)$ (Falloon,2015,2016). With the goal of enhancing the fuel for obtaining its best levels of performance and also decreasing the emissions, it should be a concentration upon the enhancements of the Octane no. that can be enhanced via adding special additives. The fuel addition are chemicals added to fuels in small quantities in order to enhance their performance or add properties that were not present in the base fuel. One of the fuel additives types which can be used are ketones (Kumar et al.,2018). Raaid Rashad Jaseem et al. (2011) investigated the influence of a conventional additive fuel upon the spark ignition engine performance. 3 kinds of additive fuel were utilized, the additives being (T-max, Gasoline additive and Gema) which were supplemented to a pure fuel as a volumetric ratio $(1 / 6,1 / 7.1$, and $1 / 8)$, correspondingly. Tests were conducted for a pure mixing fuel at different rotational speeds $(600-3000 \mathrm{rpm})$. Results revealed that the performance of engine increased by utilizing a conventional additive, the brake power increased via $(23 \%, 18 \%$ and $12.6 \%)$ when employing the gasoline mixing. Also, the brake thermal efficiency increased to maximum for (T-max) almost about (8\%) and to minimum for the gasoline additive around (3.7\%). This investigation indicated that improvement in the brake specific fuel consumption for (,T-max, Gasoline additive and Gema) is $(5 \%, 1 \%$ and $2 \%$ ), correspondingly in comparison with the pure fuel. Ashraf Elasakhany, (2017) formed fresh mixed fuels via the addition of (3-10 vol.\%) of acetone to a normal gasoline. The mixed fuels were examined for their efficiencies of energy and the emissions of pollutant employing a SI (spark-ignition) engine with a single-cylinder and 4-stroke. The engine was operated with each blend at (2600-3500 rpm). The experimental outcomes evinced that the AC3 (97 vol.\% gasoline plus 3 vol.\% ) mixed fuel possesses a benefit over the neat gasoline in the volumetric efficiency, torque, brake power, in-cylinder pressure, and temperature of exhaust gases by about $(0.9 \%, 0.45 \%, 1.3 \%, 2.3 \%$, and $0.8 \%)$, correspondingly. 
Yuanxu(2017) utilized different acetone-gasoline mixes, like (A10), (A20), (A19.5W0.5) having ( 80 vol.\% gasoline, 0.5 vol.\% water, and 19.5 vol.\% acetone), and (A19W1) having (80 vol.\% gasoline, 1 vol.\% water, and 19 vol.\% acetone) as fuels in a port-fuel injection (PFI) spark ignition (SI) engine. The performance of test fuels being compared with the G100 (gasoline) performance at different equivalence ratios $(\mathrm{U})$ within the range (0.83-1.25) and at the engine loads within the range (3-5 bar) (brake mean effective pressure). The results showed that A19W1 generally had greater ( $\left.\eta_{\mathrm{Bth}}\right)$ and lesser $\mathrm{NO}_{\mathrm{x}}, \mathrm{CO}$, and BTEX (Benzene, Toluene, Ethylbenzene, Xylene) than those of the else tested fuels. So, the water that contains the acetone-gasoline mixes could be utilized as a virtuous substituted fuel owing to the enhancement of the performance of engine as well as the emissions decrease. Ashraf. Elasakhany (2020) mixed renewable bioethanol and bio-acetone together and tested as a fresh fuel for a SI engine for the initial time. 3 various mixing rates were employed $(3,7$, and 10 $\mathrm{vol} \%$ of the bioethanol and dual bio-acetone in gasoline) and compared with each other as well as the pure gasoline. Results elucidated the rate $(10 \mathrm{vol} \%$ of bioacetone and bioethanol in gasoline) led to the highest VE, BP, and torque, in addition to the least emissions of carbon monoxide and unburnt hydrocarbons, in comparison with else fuel mixes and pure gasoline. Also, the whole fuel mixes exhibited lesser emissions and greater performance than the pure gasoline. Qijun Tang et al. (2020) mixed the ABE with the pure gasoline to make the different sample of fuels (referred as ABE10, ABE20, and ABE30). The results indicated that the highspeed SI engine fuelled with ABE30 boasted the largest power, and followed by ABE20 and ABE10, while the pure gasoline generated the lowest output power. The main goal for this work is to improve gasoline fuel characteristics by adding ketones type and study the effect of that on the performance of the engine and also the rate of different emissions which resulted from the combustion process.

\section{EXPERIMENTAL APPARATUSES}

The engine used in the experimental tests is Nissan QG18DE gasoline engine, four cylinders, 4-stroke, direct injection, natural aspirated in-line, closed water-cooled cycle with a displacement volume $(1.8 \mathrm{~L})$ and fitted with a hydraulic dynamometer. The engine has a castiron cylinder block, cylinder bore is $(80.0 \mathrm{~mm})$ and the piston stroke is $(88.0 \mathrm{~mm})$. All experimental tests were conducted in the University of Technology (mechanical engineering department). The test engines with its equipment are shown in Fig (1). The specifications of test engine are given in table (1). The schematic diagram of the experimental part is clarified in figure (2) and the definition of the parts of the system is shown in table (2).

\section{RESULTS AND DISCUSSIONS}

\section{Physical Properties of Fuel}

\section{Density}

The effect of types of cyclohexanone and doses level on the density of gasoline fuel is shown in figure (3).The figure shows that the density of gasoline fuel increases with increasing the doses level of cyclohexanone for all cases. Where, the highest increase was at (9\%).

\section{Calorific value}

The influence of the types of cyclohexanone and doses level on the Calorific value of gasoline fuel is shown in figure (4).The figure reveals that the calorific value of gasoline fuel decrease with increasing dosing level of cyclohexanone for this type. 


\section{Viscosity}

The effect of the types of cyclohexanone and doses level on the viscosity of gasoline fuel is shown in figure (5). The figure shows that the viscosity of gasoline fuel increases with increasing the doses level of cyclohexanone. The maximum value was with cyclohexanone at $(9 \%)$ is $(0.681$ mpa.s).

\section{Octane number}

The effect of cyclohexanone type with different doses levels on the octane number of gasoline fuel is shown in figure (6). The octane number of gasoline fuel increases with increasing the doses level of cyclohexanone for this type. The increasing of octane number becomes very clear at dosage $(9 \%)$.

\section{PERFORMANCE ENGINE}

\section{Brake power (B.p):}

Brake power can be defined as the power available at the crankshaft. Therefore, it is depend mainly on engine speed, as it increases with increasing this speed. Figure (7) shows this relationship between engine speed and brake power for pure fuel and for cyclohexanone blends with three doses $(3,6,9 \%)$, whereas it's clear that the increase is almost linear with respect to the brake power. Also, it was noticed that the adding of cyclohexanone to the pure fuel lead to increase the value of brake power, where the percentage of average value of brake power increased by $(10,14$ and $17.3 \%)$ for three doses $(3,6$ and $9 \%)$ respectively. This increase is due to several reasons, including increase the hydrogen and oxygen levels in blends which will lead to increase the combustion process speed. This, in turn, will ensure more efficient burning of the blend fuel. Also, with blends (cyclohexanone + gasoline) the octane number will be increased and this means that more pressure that the fuel withstands before detonating.

\section{Brake specific fuel consumption (b.s.f.c):}

The (b.s.f.c) is fuel amount consumed for obtaining of unit power. It is one of the most important performance parameters that can be used for performance comparisons of different fuels. Figure (8) shows the brake specific fuel consumption with variable speeds of engine at pure fuel and at various additive concentrations of cyclohexanone. It was noticed that the values of (b.s.f.c) will be decreased by $(5,6.5$ and $8.9 \%)$ at the addition of cyclohexanone for different doses. This is due to the increase in the rates of oxygen that leads to maximum utilization of the calorific value and the energy released.

\section{Brake thermal efficiency ( $\eta_{\text {B.The): }}$}

Brake thermal efficiency with several speeds of engine at different mixtures of cyclohexanone is presented in Figure (9). It is found that the brake thermal efficiency improved when using cyclohexanone and increased by (3.39, 7 and 8.98\%) with increasing dose ranging respectively. This is related to the improvement in combustion due to the oxygen content in the molecules of cyclohexanone and also to the octane raising associated with increase in percentage cyclohexanone addition.

\section{Volumetric efficiency $\left(n_{Y}\right)$ :}

Volumetric Efficiency is one of the most important factors of an internal combustion engine' performance parameters because of its direct effect on combustion quality. Figure (10), shows an increment in the $\left(\eta_{v}\right)$ in every mixt of cyclohexanone. The percentage average value will be increased by $(5.61,8.81$ and $12.7 \%)$ by adding $(3,6$ and $9 \%)$ from cyclohexanone. This is 
due to higher evaporation possessed by this ketone. The cooling effect of the evaporation of these ketones results in the temperature at the intake manifold to be low and raises the $\left(\eta_{\mathrm{v}}\right)$ due to the increase of the inlet air density. It is stated that this ketone has a higher burning temperature than the gasoline, this means that the further heat of evaporation than the gasoline results in the temperature at intake manifold to be lesser and raises the $\left(\eta_{v}\right)$.

\section{Brake mean effective pressure (b.m.e.p):}

Figure (11) shows the increase of brake mean effective pressure when the engine speed increase for pure fuel and when adding the cyclohexanone. The behavior of these curves is similar to those in brake power because the mean effective pressure is depend on brake power, it is increase when brake power increase. The brake mean effective pressure of cyclohexanone will be increased by $(10.25,14.24$ and $17.25 \%)$ for $(3,6$ and $9 \%)$ respectively.

\section{EMISSIONS}

\section{Carbon dioxide $\left(\mathrm{CO}_{2}\right)$}

Figure (12) shows the percentage average value of $\left(\mathrm{CO}_{2}\right)$ for cyclohexanone and how it is increase when the engine speed increase but decrease when the concentration of cyclohexanone increase. The rates of $\left(\mathrm{CO}_{2}\right)$ for three concentrations of cyclohexanone will be decreased by 27.72, 26.39 and 22.43\%) at adding (3, 6 and 9\%) of cyclohexanone respectively. In the case of engine speed, the increase which happen in the rated of $\left(\mathrm{CO}_{2}\right)$ because the increase of temperature and pressure this will lead to more rate of oxidation of blends. While, the decreasing in the average percentage of $\left(\mathrm{CO}_{2}\right)$ when using cyclohexanone, the reason is due to complete combustion of blends because of the high content amount of oxygen in cyclohexanone, this will lead to consume less amount of fuel.

\section{Carbon monoxide (CO) and unburnt hydrogen (UHC)}

$\mathrm{CO}$ emission occurs due to incomplete combustion or insufficient oxygen during combustion or due dissociation of $\mathrm{CO}_{2}$, while the (UHC) will be formed due to unequal ratios between fuel and air and also because of incomplete combustion. Figure (13) and (14) shows the (CO) and (UHC) emissions change with speed respectively, it will be recorded that high values noticed at low and medium speeds and it starts decreasing again at high speed. This due to increasing the temperature of combustion chamber, this will lead to increase oxidation and decrease (CO) and (UHC). In addition, the decomposition of hydrocarbon in high temperature leads to decrease the $(\mathrm{CO})$. In the case of blends, for three types of cyclohexanone and when the concentration of ketone increase, the percentage average value of these emissions will be decrease. For $(\mathrm{CO})$, the rates of carbon monoxide will be decrease by $(25.18,28.2$ and $35.02 \%)$ for cyclohexanone. While (UHC) will decreased by $(27.78,33.12$ and $49.04 \%)$ for cyclohexanone at $(3,6$ and $9 \%)$ of cyclohexanone respectively. This reduction when using cyclohexanone is due to high rates of oxygen content in cyclohexanone compared to pure fuel and this lead to make the combustion process more complete.

\section{Nitrogen Oxides $\left(\mathrm{NO}_{\mathrm{x}}\right)$}

It is compound of oxygen and nitrogen that is formed by reacting with each other during combustion at high temperatures. Figure (15) presents the variation of $\left(\mathrm{NO}_{\mathrm{X}}\right)$ with the engine speed for the tested gasoline fuels. The largest amount of $\left(\mathrm{NO}_{\mathrm{X}}\right)$ is usually found at high speed (2200 r.p.m), at which the temperature and pressure are the highest. In the case of fuel blends, the rate of $\left(\mathrm{NO}_{\mathrm{X}}\right)$ will be decreased by $(23.67,38.43$ and $42.14 \%)$ at doses $(3,6$ and $9 \%$ ) for cyclohexanone. This reduction rate is due to complete combustion of the blended fuel 
which consumes the most oxygen in combustion zone and reduce the chance of $\mathrm{NO}_{\mathrm{X}}$ formation despite of temperature rise.

\section{HEAT BALANCE}

It is the distribution of the heat energy supplied to a thermo-mechanical system among the various drains upon it including both useful output and losses. The results of useful and the losses heat which obtained from experimental test will be displayed and discussed for each cyclohexanone in the next paragraph as following:

Figures (16) and ((17A), (17B) and (17C)) shows that the heat balance beside brake power which results due to combustion process for cyclohexanone with concentrations $(3,6$ and 9\%). It was noticed that the value of total energy supplied (Qт) will be increased with the increase of engine speed, the reason for this is due to increase the rate of fuel consumption $\left(\dot{m}_{f}\right)$ and this make most utilization of calorific value. In the case of blends, the (QT) will be increased by $(5.06,5.59$ and $6.59 \%)$ when adding cyclohexanone. In the case of heat rejected to cooling water $\left(\mathrm{Q}_{W}\right)$, also will be increased when engine speed increase due to increase mass flow rate of water $\left(\dot{m}_{w}\right)$ and also increase the temperature of water which enter and exit from the engine. For the blends, the $\left(Q_{w}\right)$ will be increased by $(2.44$ and $0.97 \%)$ for ratios (3 and $9 \%)$ and decreased by $(1.91 \%)$ for ratio $(6 \%)$ when adding cyclohexanone. The heat loss to exhaust $\left(Q_{e \times h_{1}}\right)$, also depend directly on engine speed. The increment rate of $\left(Q_{a \times h}\right)$ is return to the increase of mass flow rate of air $\left(\dot{m}_{a}\right)$ and mass flow rate of fuel $\left(\dot{m}_{f}\right)$ and also due to increase the exhaust temperature. For the blends, the $\left(Q_{a x h}\right)$ will be increased by $(1.79$ and $1.69 \%$ ) for ratios (3 and $9 \%$ ) and decreased by $(1.11 \%)$ for ratio $(6 \%)$ for cyclohexanone. The unaccountable heat loss $\left(\mathrm{Q}_{\mathrm{un}}\right)$, which consider as a heat loss due to heat transfer, friction power, and operation of axillary devices $\left(Q_{t}\right)$, will increase with increasing of engine speed. It will be increased by $(5.57,17.85$ and $2.07 \%)$ for ratios $(3,6$ and $9 \%)$ of cyclohexanone.

\section{EXHAUST GAS TEMPERATURE}

Figure (18) shows the variation of exhaust gas temperature with the engine speed for the tested gasoline fuels and blends for cyclohexanone type at all range of engine speed. The results demonstrated that the exhaust gas temperatures increased with increasing the engine speeds for pure fuel and also for blends. From the results, it was noticed that the exhaust temperature for blends will be higher compared with pure fuel. It will be increased by $(25.93$, 27.54 and $28.31 \%$ ) for cyclohexanone at (3,6 and 9\%) respectively. This is due to the increase in the octane number of the blended fuels which lead to more efficient combustion that associated with rising of combustion temperature. The increment in exhaust temperature is also due to the enhancement in combustion process and increases in oxidation process of carbon and oxygen.

\section{CONCLUSIONS}

This study focuses the effect of using fuel additive (ketones) on the performance and emissions on SI engine. The following conclusions may be highlighted from this study:

1. The type used is cyclohexanone with three concentrations (3, 6 and $9 \%)$ to improve the engine performance, reduce the emissions which results from combustion process and enhance the physical properties of gasoline fuel.

2 . It could be concluded that the $(9 \%)$ percent blend of cyclohexanone with pure gasoline fuel can be observed is the best blend in regard to performance and exhaust emission characteristics as compared to all other blends. 
Table 1. Tested engine specifications

\begin{tabular}{|l|l|}
\hline Manufacturer & Nissan (Aguascalientes, Yokohama, Atsuta Plant) \\
\hline Mark & QG18DE \\
\hline Fuel type & Gasoline \\
\hline Fuel system & Multi point fuel injection (MFI) \\
\hline Cylinder alloy & Cast iron \\
\hline Engine type & Four stroke, Inline-4 (straight-4) \\
\hline displacement & 1.8 liter \\
\hline Engine oil capacity & $2.7 \mathrm{~L}$ \\
\hline Power & $85.3-94 \mathrm{~kW}$ \\
\hline Torque moment & $163-176 \mathrm{Nm}$ (at 2800 rpm) \\
\hline Cylinder bore & $80 \mathrm{~mm}$ \\
\hline Piston stroke & $88 \mathrm{~mm}$ \\
\hline Compression ratio & $9.5: 1$ \\
\hline Intake valve diameter & $30.2 \mathrm{~mm}$ \\
\hline Exhaust valve diameter & $25.2 \mathrm{~mm}$ \\
\hline Number of main bearings & 5 \\
\hline
\end{tabular}

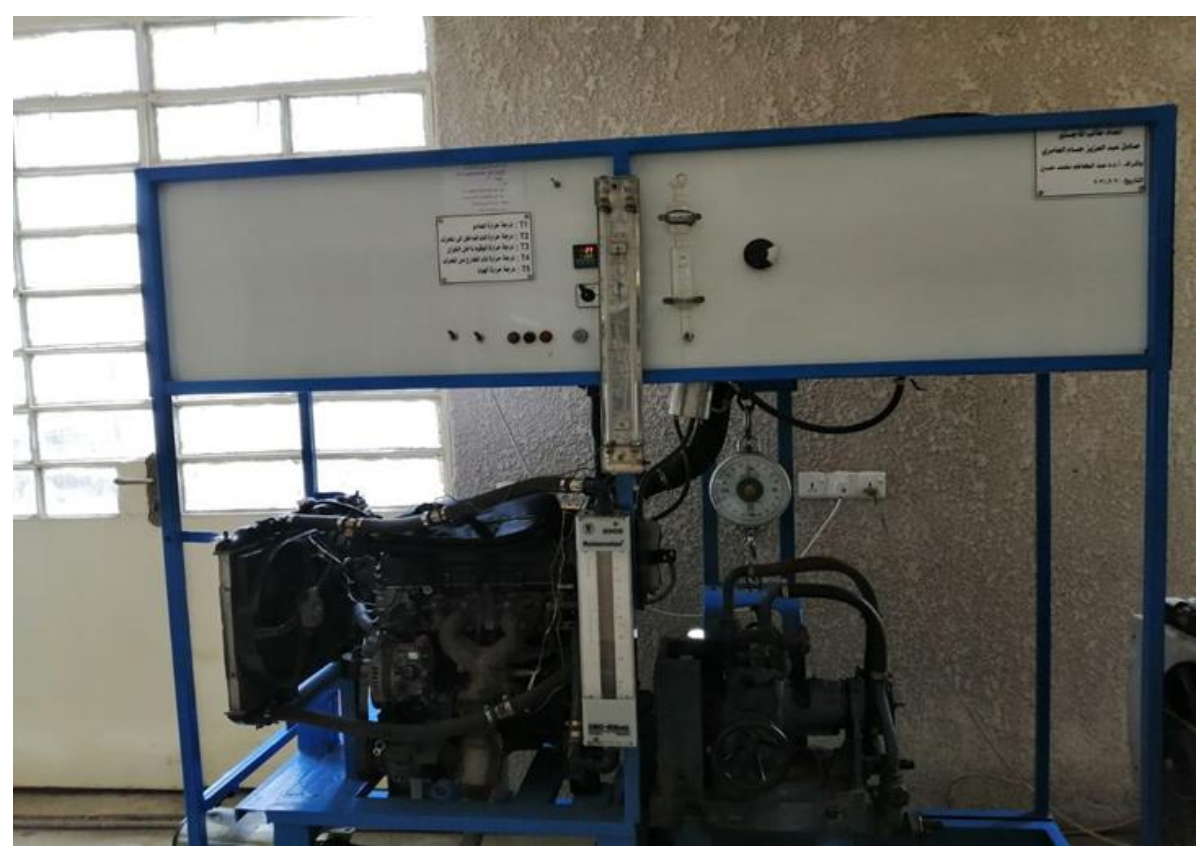

Fig.1. The test engine. 


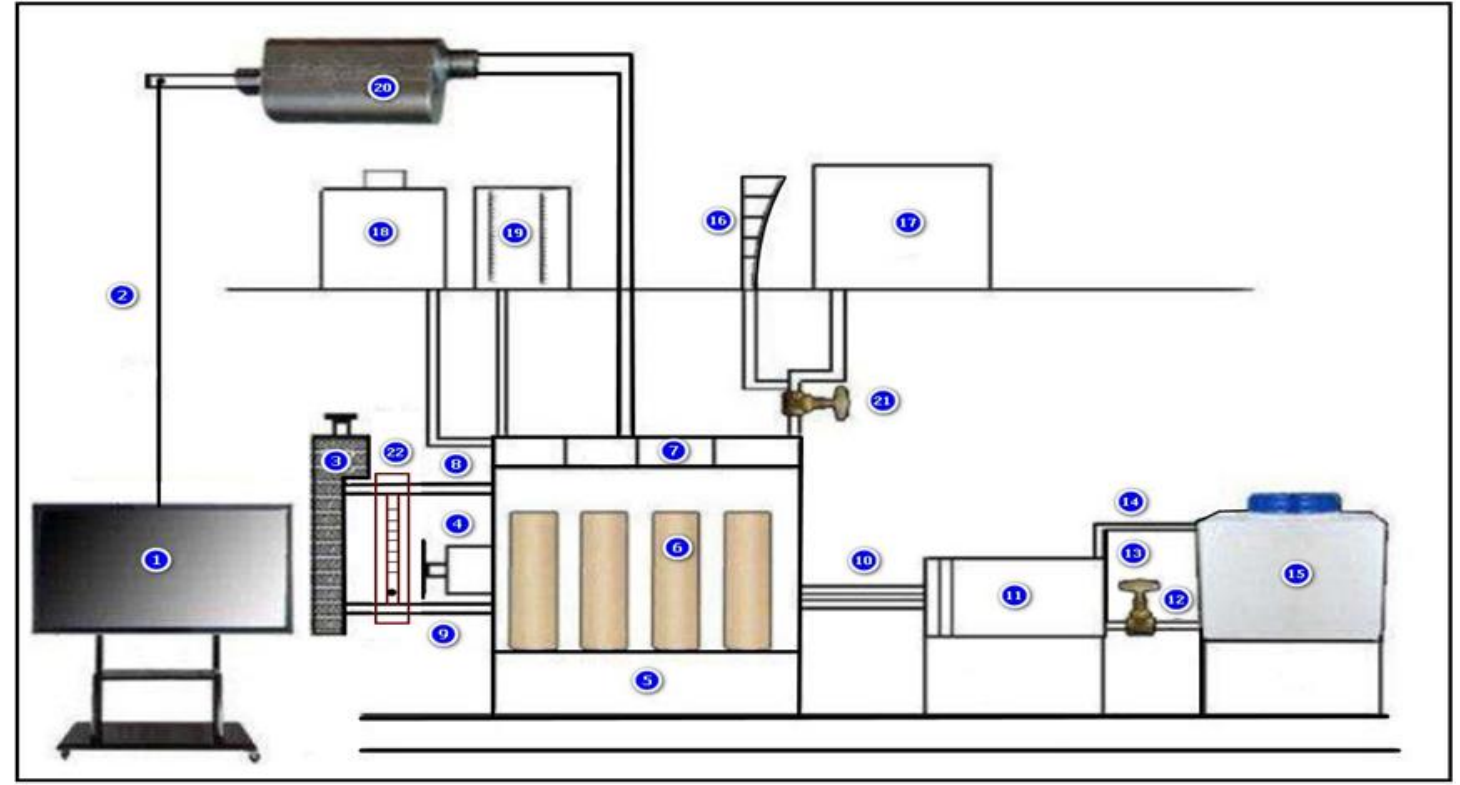

Fig.2. Schematic diagram of the experimental set up

Table 2. Definitions of the parts of the system in figure 2 .

\begin{tabular}{|l|l|l|l|}
\hline 1 & Gas analyzer & 12 & Inlet water to the dynamometer \\
\hline 2 & Prop of gas analyzer & 13 & The valve of water tank \\
\hline 3 & Radiator & 14 & outlet water from dynamometer \\
\hline 4 & Engine fan & 15 & Water tank \\
\hline 5 & The test engine & 16 & Fuel consumption meter \\
\hline 6 & Cylinders of engine & 17 & Fuel tank \\
\hline 7 & Cylinder head & 18 & Air surge tank \\
\hline 8 & outlet water from engine & 19 & Manometer \\
\hline 9 & Inlet water to engine & 20 & Silencer \\
\hline 10 & coplent link & 21 & The valve of the fuel tank \\
\hline 11 & Hydraulic dynamometer & 22 & Flow meter \\
\hline
\end{tabular}

Table 3. Physical properties of blends (cyclohexanone + fuel)

\begin{tabular}{|l|l|l|l|l|}
\hline Sample name & $\begin{array}{l}\text { Calorific value } \\
(\mathbf{k j} / \mathbf{k g})\end{array}$ & $\begin{array}{l}\text { Density } \\
\left(\mathbf{k g} / \mathbf{m}^{\mathbf{3}}\right)\end{array}$ & $\begin{array}{l}\text { Viscosity } \\
\mathbf{m p a .} \text { S }\end{array}$ & $\begin{array}{l}\text { Octane number } \\
\text { at 16.5 } \mathbf{c}^{\mathbf{0}}\end{array}$ \\
\hline $\begin{array}{l}\text { Gasoline } \\
\text { (pure fuel) }\end{array}$ & 43000 & 710 & 0.551 & 86 \\
\hline $\begin{array}{l}\text { 3\% cyclohexanone+ } \\
\text { 97\% gasoline }\end{array}$ & 42685.448 & 720.5 & 0.650 & 91.2 \\
\hline $\begin{array}{l}\text { 6\% cyclohexanone+ } \\
\text { 94\% gasoline }\end{array}$ & 42376.16 & 730.814 & 0.592 & 94.8 \\
\hline $\begin{array}{l}9 \% \text { cyclohexanone+ } \\
\text { 91\% gasoline }\end{array}$ & 42077.5 & 740.8 & 0.681 & 97.7 \\
\hline
\end{tabular}




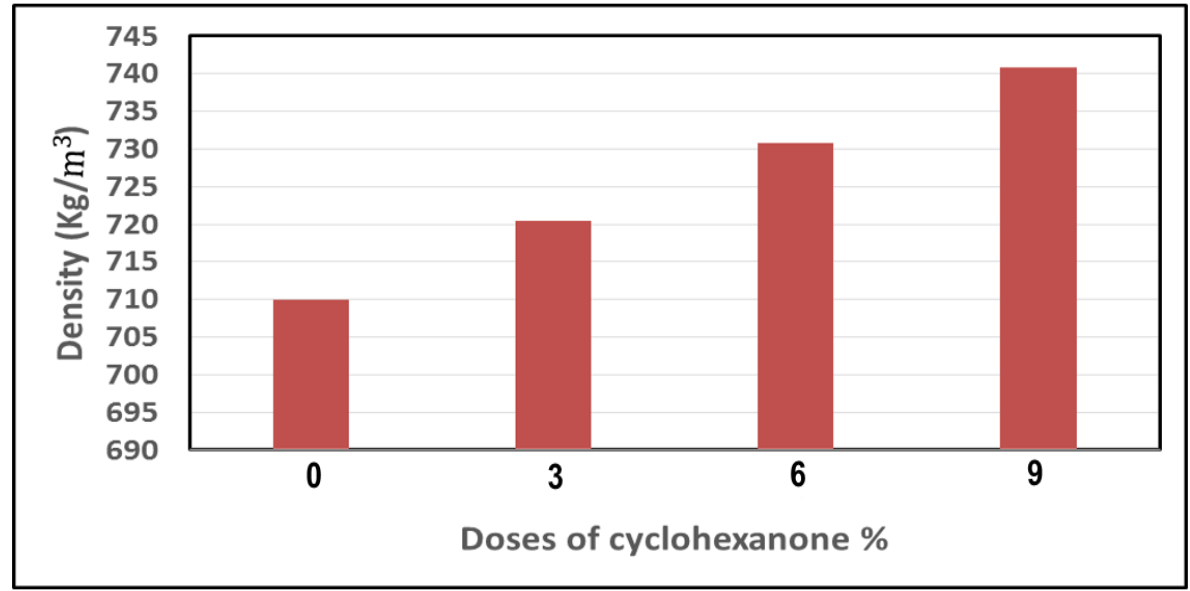

Fig.3. Variation of density with cyclohexanone doses

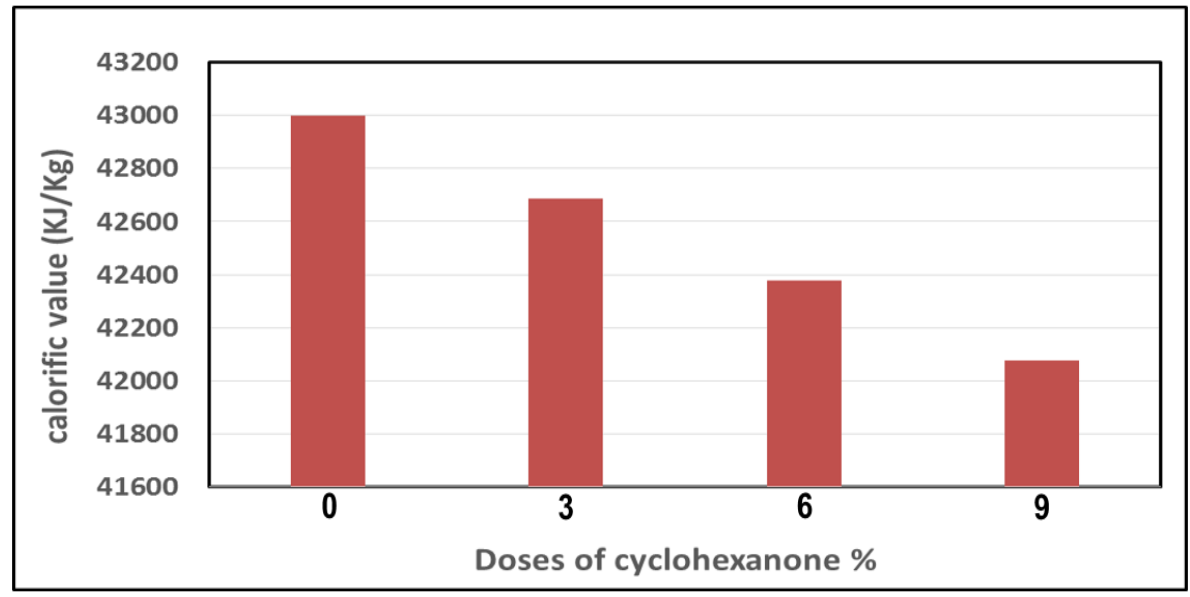

Fig.4. Variation of Calorific value with cyclohexanone doses

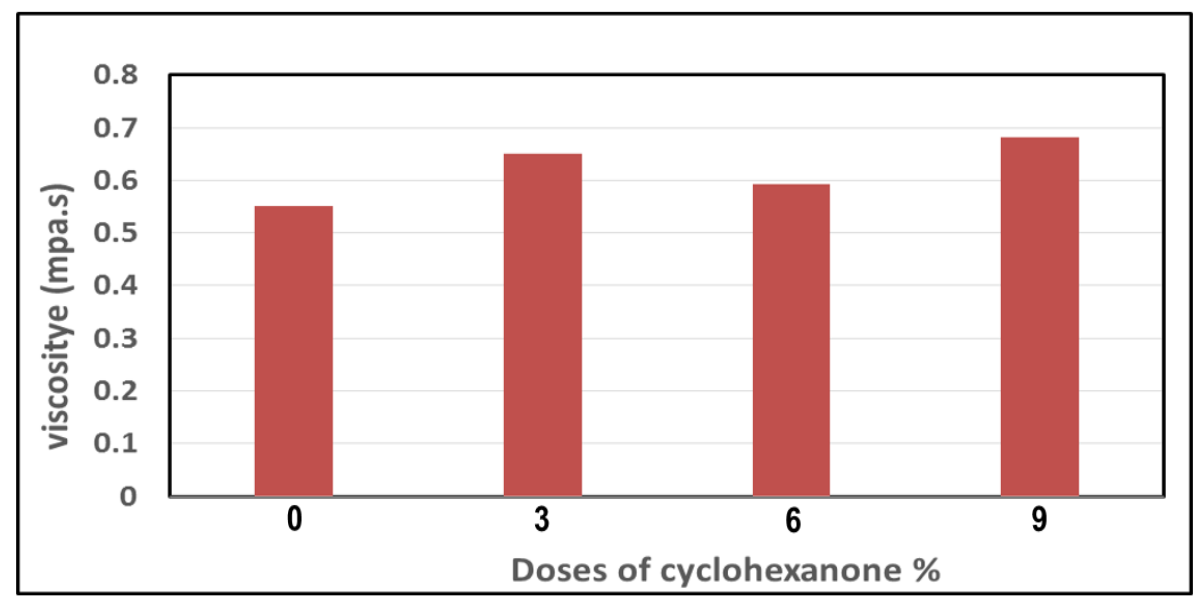

Fig.5. Variation of Viscosity with cyclohexanone doses 


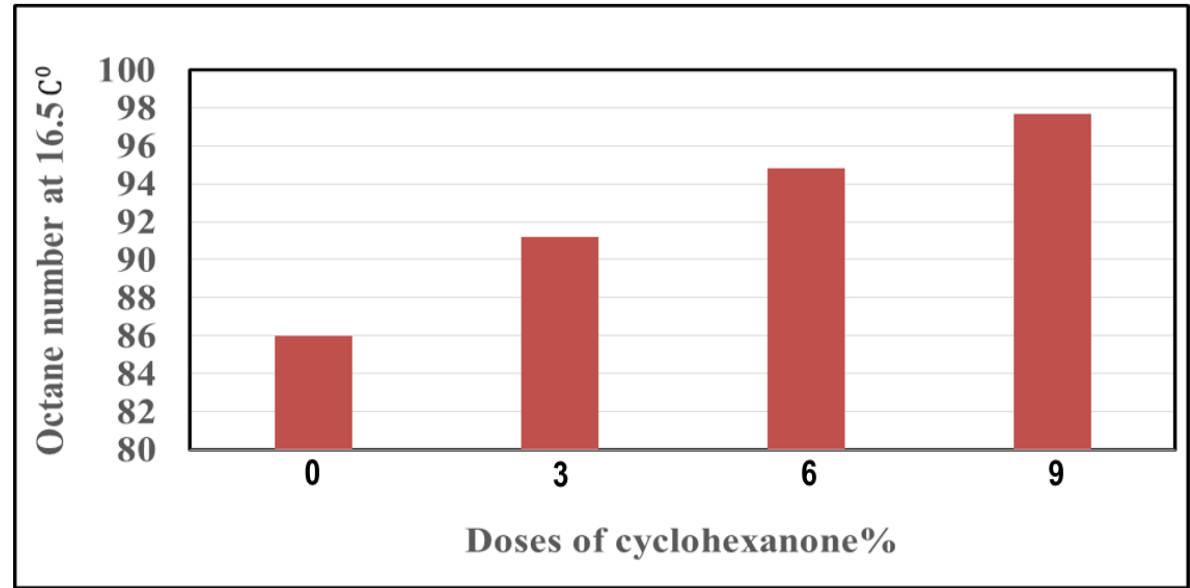

Fig.6. Variation of octane number with cyclohexanone doses.

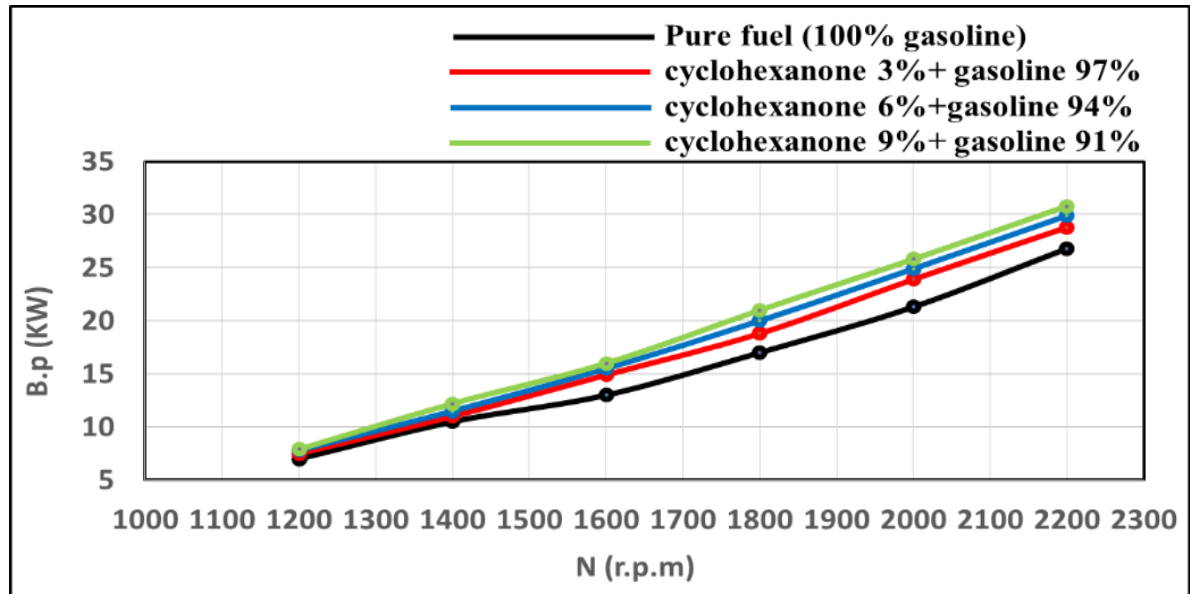

Fig.7. Effect speed on brake power for cyclohexanone

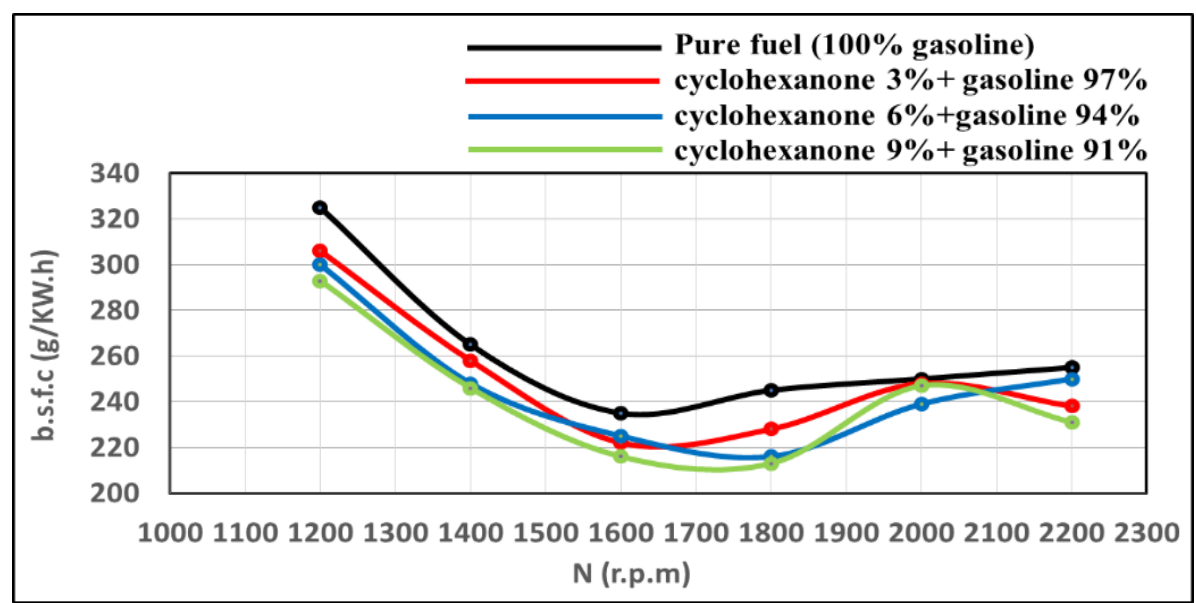

Fig.8. Effect speed on (b.s.f.c) for cyclohexanone 


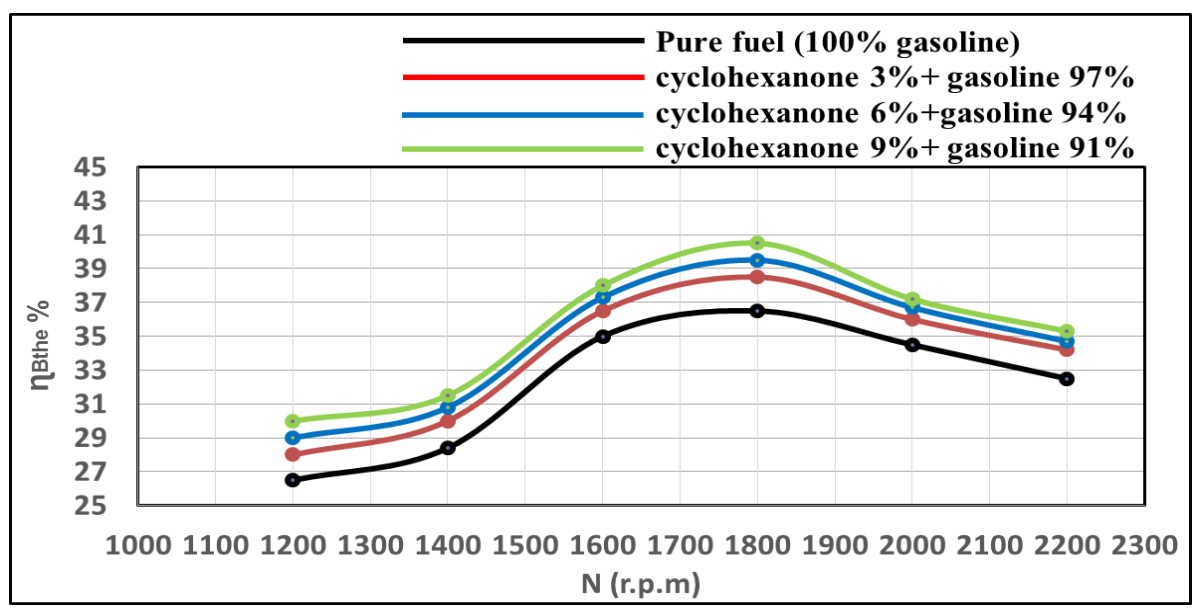

Fig.9. Effect speed on Brake thermal efficiency for cyclohexanone.

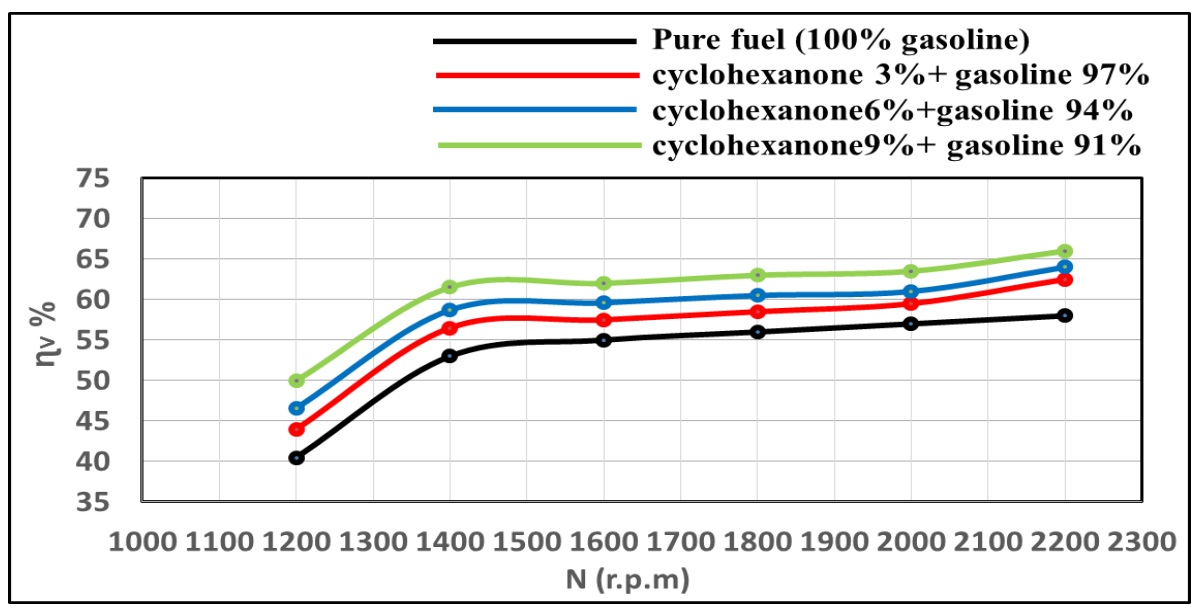

Fig.10. Effect speed on Volumetric efficiency for cyclohexanone.

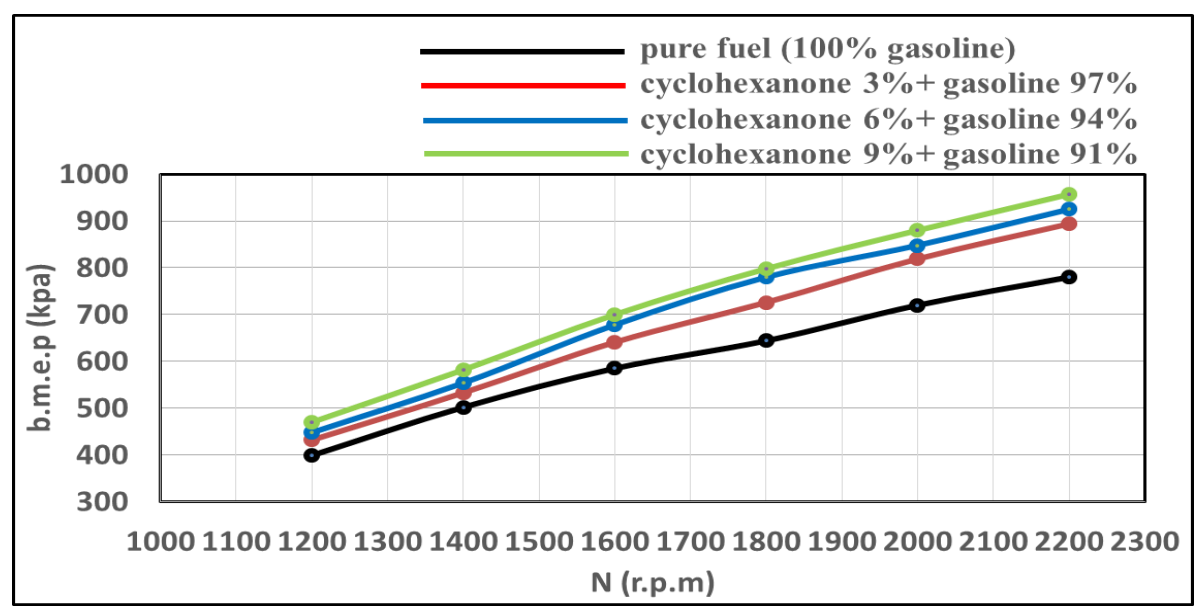

Fig.11. Effect speed on (b.m.e.p) for cyclohexanone. 


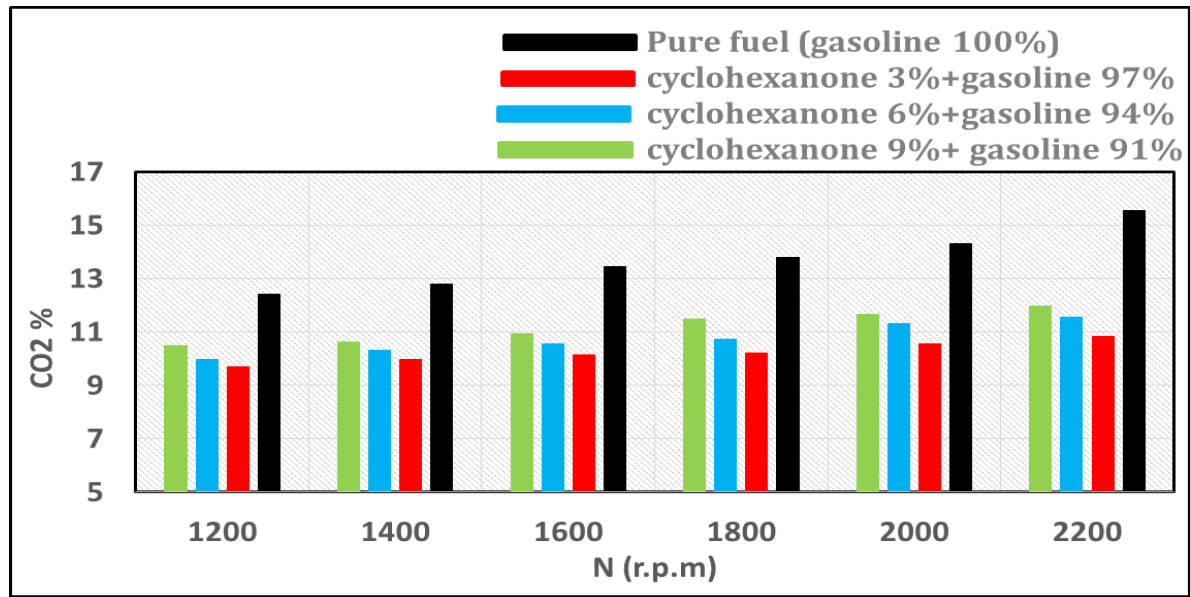

Fig.12. Effect speed on $\mathrm{CO}_{2}$ emission for cyclohexanone.

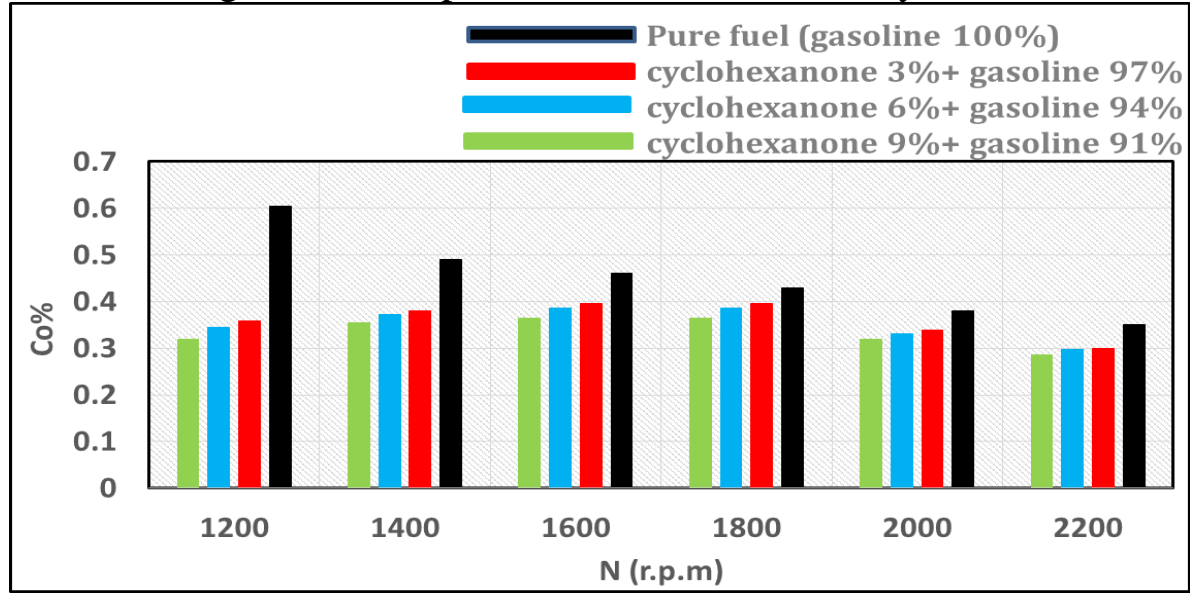

Fig. 13. Effect speed on $\mathrm{CO}$ emission for cyclohexanone.

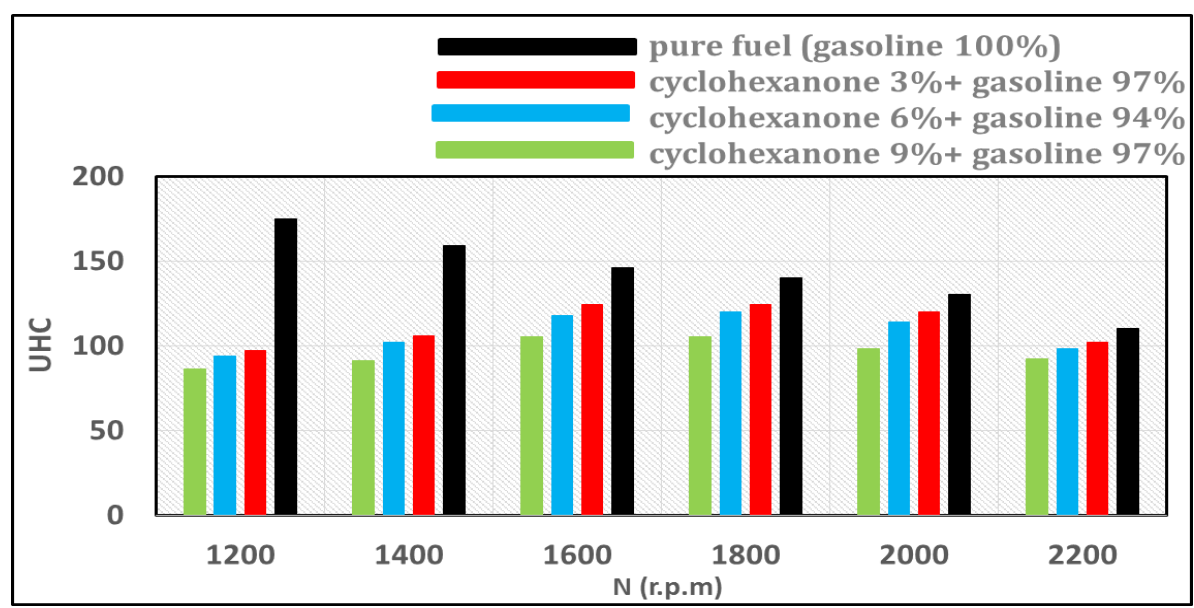

Fig.14. Effect speed on UHC emission for cyclohexanone. 


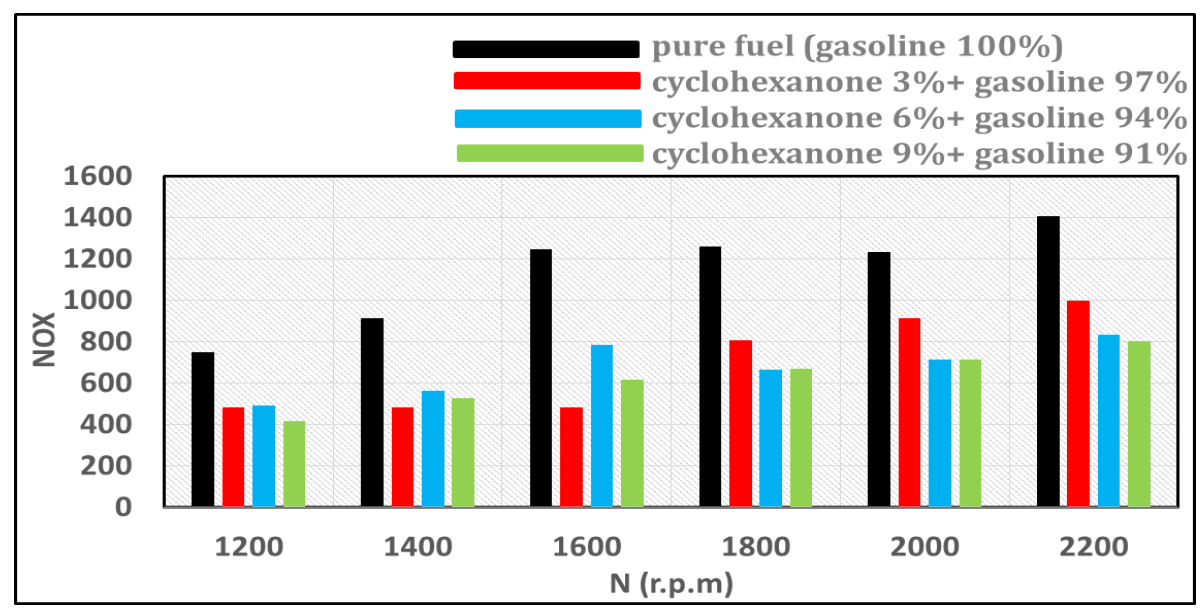

Fig.15. Effect speed on NOx emission for cyclohexanone.

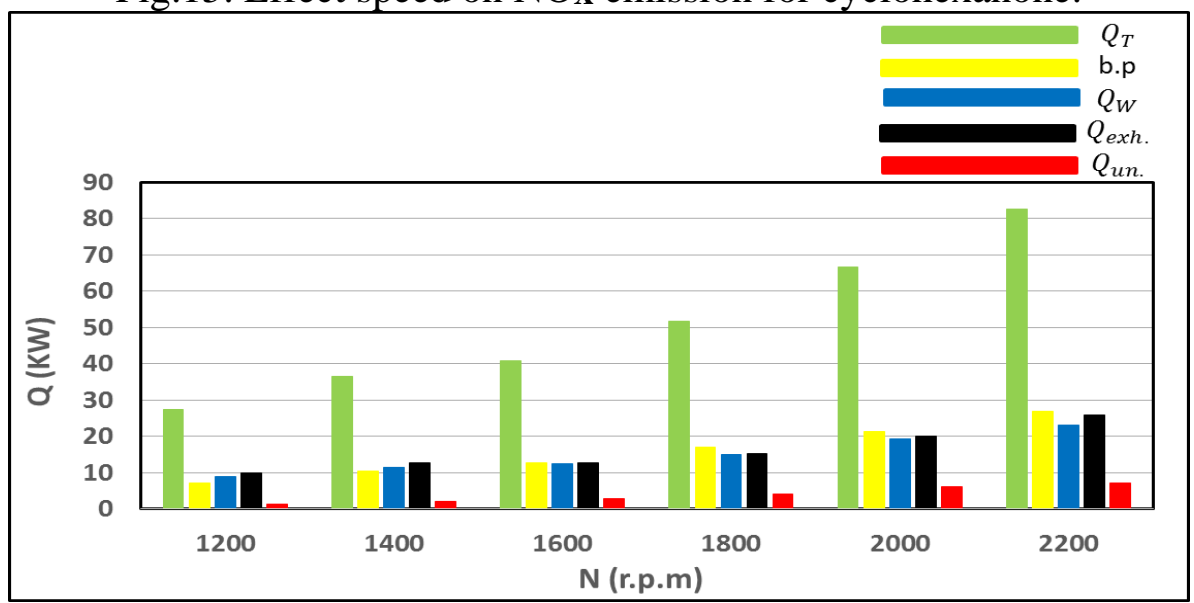

Fig.16. Effect speed on heat balance for pure fuel

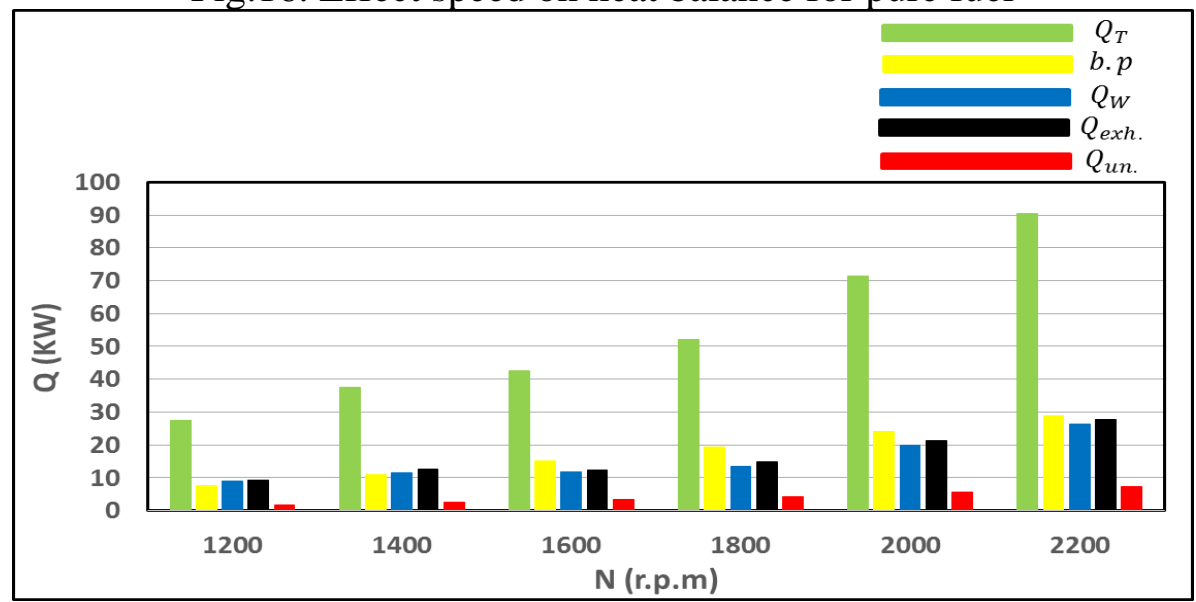

(a)(3\%) Cyclohexanone. 


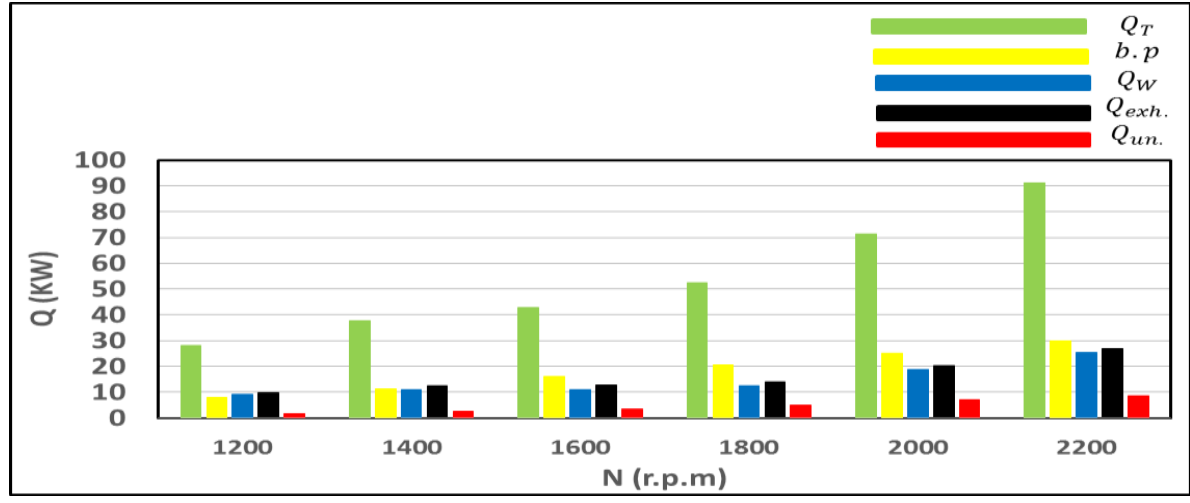

(b) (6\%) Cyclohexanone

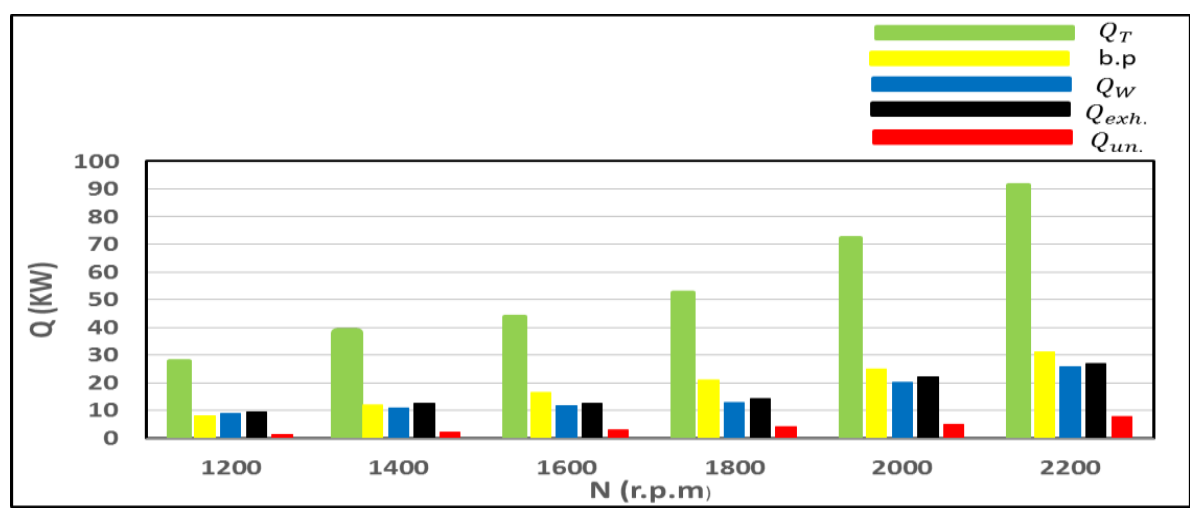

(c) (9\%) Cyclohexanone

Fig.17. Heat balance for cyclohexanone.

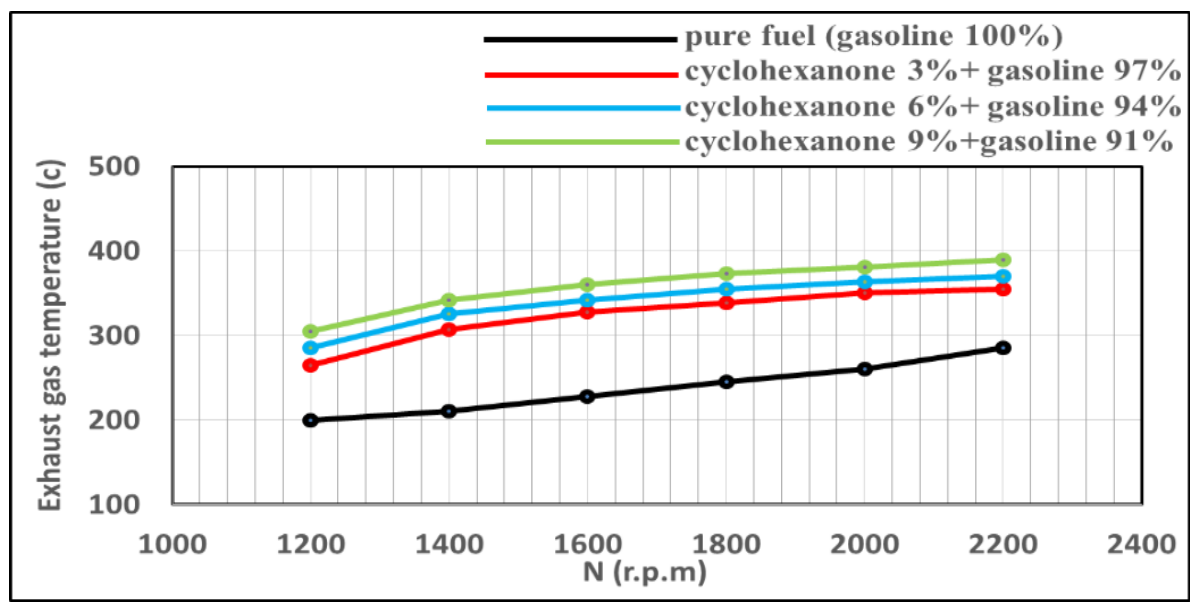

Fig.18. Effect speed on exhaust temperature for cyclohexanone.

\section{REFERENCES}

Abdel-Rahman, A. A., "On the emissions from internal-combustion engines: a review", International Journal of Energy Research, vol. 22(6), pp.483-513, 1998.

Adel, Mahmood S. " Engine Performance and Emission Fueled with Blends of Bioethanol-Gasoline.", University of technology, (2018). 
Adel, Mahmood S. "The Emitted Noise from a Spark Ignition Engine Fueled by Methanol Added to Gasoline.", University of technology, (2018).

Elfasakhany, Ashraf. "Investigations on performance and pollutant emissions of sparkignition engines fueled with n-butanol-, isobutanol-, ethanol-, methanol-, and acetonegasoline blends: A comparative study." Renewable and sustainable energy reviews, vol.71, pp. 404-413, (2017).

Elfasakhany, Ashraf. "Gasoline engine fueled with bioethanol-bio-acetone-gasoline blends: Performance and emissions exploration." ELSEVIER, vol. 274 pp. 117825, (2020).

Falloon, T., "Effect of fuel additives in a natural gas and gasoline engine", The (Doctoral dissertation, Colorado State University). (2016)

Heywood J.B., "Internal Combustion Engine Fundamentals\|", Copy right by McGraw-Hill, $2^{\text {nd }} \operatorname{Ed}(1989)$.

Holman, J. "Heat Transfer " $10^{\text {th }} \mathrm{Ed}(2009)$.

Kumar, M. V., Babu, A. V., \& Kumar, P. R., "The impacts on combustion, performance and emissions of biodiesel by using additives in direct injection diesel engine", Alexandria Engineering Journal, vol. 57(1), pp. 509-516, (2018).

Lawal, D. U., Imteyaz, B. A., Abdelkarim, A. M., \& Khalifa, A. E., "Performance of spark ignition engine using gasoline-91 and gasoline-95", International Journal of Innovative Science, Engineering and Technology, vol. 1(6), (2014).

Li, Y., Nithyanandan, K., Meng, X., Lee, T. H., Li, Y., Chia-fon, F. L., \& Ning, Z., "Experimental study on combustion and emission performance of a spark-ignition engine fueled with water containing acetone-gasoline blends Fuel", vol.210, pp. 133-144, (2017)

Mägi, Mart., "Effect of Gasoline Fuel Additives on Combustion and Engine Performance", Diss. UCL (University College London), (2015).

Pulkrabek, Willard W. "Engineering fundamentals of the internal combustion engine." Journal of engineering for gas turbines and power, (2004), pp. 198-198. $2^{\text {nd }} \mathrm{Ed}(2004)$

Rashad Jaseem, R., K Salim, T., \& Thamer Nazzal, I., "An Experimental Investigation of the Effect of Traditional Enhancement on Spark Ignition Engine Performance", Kirkuk University Journal-Scientific Studies, vol. 6(2), pp. 1-14, (2011).

Tang, Q., Duan, X., Liu, Y., Li, S., Zhao, Z., Ren, K., \& Chang, H., "Experimental study the effects of acetone-butanol-ethanol (ABE), spark timing and lambda on the performance and emissions characteristics of a high-speed SI engine", ELSEVIER, vol. 279, pp. 118499, (2020). 